\title{
RESENHA
}

\section{TESTAMENTO INTELECTUAL}

\author{
Milton Santos \\ S. Paulo: EDUNESP, 2004
}

Testamento intelectual é o texto do projeto retrospectivo-projetivo de um pensador que morreu ao mesmo tempo esperançoso e amargurado. Esperançoso de haver ainda tempo de deixar sua reflexão crítico-avaliativa da trajetória seguida pela geografia no Brasil e no mundo num período cuja presença é um ponto de referência inquestionável. Amargurado de ver esta evolução confluir para a consagração exatamente de tudo aquilo contra o qual lutara. A morte abateu Milton Santos antes que ele pudesse transformar seu roteiro num livro.

Talvez não haja livro, nem mesmo dentre os escritos de Milton Santos, que melhor espelhe este quadro ambivalente da história recente da geografia brasileira. Sua força e sua fragilidade encontram-se aqui simetricamente igualadas. Por outro lado, nenhum melhor para mostrar que um estudo detalhado e cuidadoso da obra de Milton Santos está ainda por se fazer, sem a apologia e o culto à personalidade que face sua morte hoje o cerca. O que sua obra traz de originalidade própria e como ela se classifica ao lado das outras tantas originalidades que a história do pensamento geográfico originou e dispôs através das produções de outros tantos pensadores, alguns dos quais Milton toma como muitas de suas próprias referências.

É hora de vermos um autor, sua obra e seu pensamento pelo que tem de original e singular, não de superior ou inferior a outro. Isto enriquece a bibliografia de um campo acadêmico e oferece a seus intelectuais um amplo leque de alternativas de referências de trabalho.

O fato é que não se consolida a obra de nenhum pensador que aos olhos dos pósteros apareça como o estágio superior de toda uma evolução de idéias, as quais surgiriam como plataforma do seu surgimento e em relação à qual sejam vistas como estágios de uma linha de progresso sucessivamente superior e para frente. Este tipo de leitura que classifica os intelectuais como pré e pós um intelectual de referência só alimenta a ideologia dos modismos e é o caminho mais reto para um 
próximo esquecimento. Milton Santos não deve ser assim visto e não merece que assim o tratemos. Sua obra é uma forma extremamente original e espelha a personalidade de um homem orientado numa forma criativa e absolutamente própria de ver o mundo. Não inferior, nem superior a qualquer outro. Genialmente próprio.

É isto o que nos chama atenção no seu Testamento Intelectual. É o projeto de um intelectual chamado a fazer o balanço de todo um movimento de idéias em que se fez presente e que ajudou sobremaneira a impactar com sua arguta ironia e inteligência. O livro divide-se em duas partes, tratando ambas de um mesmo tema: Entrevista, onde Milton deixa sua reflexão sobre uma riqueza de temas do tempo e da geografia por ele vividos; e Depoimentos sobre a geografia: testamento intelectual, onde arrola ele a sequiência dos assuntos que gostaria de investigar e desenvolver em livro, oferecendo seu pronunciamento e seu balanço definitivo sobre a transformação e o desenvolvimento de um saber ao qual dedicou inteiramente sua carreira acadêmica e sua vida. Muito das opiniões, detectação de problemas, apreciação dos dilemas e avaliações de um tempo e do saber geográfico como hoje se encontra e a parcela de enriquecimento que lhe coube trazer se repetem nessas duas partes. Completa-as uma rica iconografia.

O título do livro vem da segunda parte. A rigor, é um testemunho e ao mesmo tempo uma agenda de intenções que inafortunadamente (para nós particularmente) a doença bloqueou definitivamente.

Seu testemunho seria de uma inestimável valia para nosso conhecimento. Poucos geógrafos conviveram com uma plêiade tão grande de pensadores brasileiros e de todos os cantos do mundo, responsáveis, como ele, pelo construção da geografia que hoje temos. Como não seria interessante sabermos os bastidores dessa construção, os sonhos e os projetos que ficaram no meio do caminho, as idéias que mesmo quando vêm ao livro não trazem o mesmo frescor da forma e do ambiente em que se originaram, os inter-relacionamentos de pessoas que só de longe conhecemos!

Em particular, o que não teria a dizer sobre a atual quadra da geografia brasileira, anos depois de acúmulos de debates e mudanças, seu progresso palpável e a diluição da expectativa justamente estimuladora desse progresso por conta de um etos acadêmico fragmentário, paroquial e o mais das vezes de conteúdo cênico que acabou prevalecendo. 